GLOBAL JOURNAL OF SOCIAL SCIENCES VOL 17, 2018: 109-116

COPYRIGHTC BACHUDO SCIENCE CO. LTD PRINTED IN NIGERIA. ISSN 1596-6216

\title{
MEDICINE AND POLITICS: THE CONVERGENCE FROM A NIGERIAN PERSPECTIVE
}

\section{KALADA GODSON MCFUBARA AND AMBILY ETEKPE}

(Received 24 July 2017; Revision Accepted 8 November 2017)

\begin{abstract}
Although medicine and politics are distinct subjects and among the oldest professions, there have been calls for medical doctors to get involved in active politics. Thus this study sought to identify and describe the relationship between medicine and politics by doing conceptual analysis of themes that are common to both disciplines. It was found that the relationship between medicine and politics has not been properly examined, especially from the Nigerian perspective. But the two professions are found to be related in the field of Social Sciences in the areas of their practitioners' calling and levels of their operation. The paper however argued that when medical practitioners abandon their duty of care to patients and seek to acquiesce to politics it is because there is a sense of loss of the leadership influence among them in the body politics of society. It concludes by suggesting that the loss can best be retrieved from the health discipline of public health, which is the point of convergence of both professions.
\end{abstract}

KEYWORDS: Leadership, Public health, public policy, politics, public interest.

\section{INTRODUCTION}

In Nigeria we often read about the influence that medicine exerts upon the national polity especially in health politics. Yet there is little academic literature to explain the relationship between medicine and politics. In ancient times philosophers like Hippocrates and Plato nitched themselves in both professions in order to develop their people by producing the greatest good for the greatest number. In 2005 at the first Professor Grillo lecture, by the Alumni at Obafemi Awolowo University, Dr. Mamora, a medical doctor and distinguished former Senator of the Federal Republic of Nigeria said that most doctors keep away from active politics (Mamora, 2005), suggesting that they are in passive politics. However by this Dr Mamora suggests a relationship between medicine and politics by, on one hand calling both Siamese twins, and on another calling medicine the wife and politics the mistress. But he failed to make clear the basis of their relationship.

In 2014, Wale Okediran an honourable member of the House of Representatives also advised his medical colleagues not to distance themselves from politics. According to him the reason is that politicians like doctors make decisions for allocation of resources that affect the interest of the people (Okediran, 2014). Whether both parliamentarians would agree that politicians should not distance themselves from the decisions doctors make is another subject matter. Be that as it may, both parliamentarians understand that there is a relationship between medicine and politics. However, the call for doctors to get involved in active politics tells of a

Kalada Godson McFubara, Department of Community Medicine, Niger Delta University, Bayelsa State, Nigeria.

Ambily Etekpe, Department of Political Science, Niger Delta University, Bayelsa State, Nigeria.

C) 2018 Bachudo Science Co. Ltd. This work is licensed under Creative Commons Attribution 4.0 International license. 
gap in medicine that seeks to be filled by acquiescing to politics. That gap is captured in the behavioural theory of leadership that says that leaders are made (http://changingminds.com/discipline/leadership).

If decision-making in resource allocation is the reason for doctors to get involved in active politics, are they prepared for that task? If they are, in what way is it and if not, how can they be? This paper examined the relationship between medicine and politics to identify their point of convergence. Concepts that occur in both are identified and themes are developed for analyzing their relationship.

Political decision-making in the health service In both medicine and politics decision-making is a leadership behaviour that can be conducted at bureaucratic, interest group or corporate levels. The lack of this knowledge means the health sector in Nigeria has suffered so much underdevelopment. When examined critically, this underdevelopment can be traced to a misapplication of human and material resources. An example was in 1984 when the Nigerian Medical Association (NMA) pressed for and got the exclusive concession of a medical doctor as Minister of Health (Democrat, 21 October, 1984:12). This is irrespective of the specialty of the doctor. But why the NMA thinks a non medical doctor cannot be a Minister of Health is not yet clear. Even so, doctor ministers have not made exceptional impact in the health system. For instance, from 1980 up until 2017, there were incessant strikes by doctors. At the same time before 2013 medical tourism alone, gulped over 78 billion naira annually, with India attracting 260 million dollars. These figures were estimated to rise to between 1 and 2 billion dollars by 2013 (National Daily, 20/12/13 p. 33). In 2014 the rise was confirmed with Nigeria losing 250 billion naira annually to medical tourism (nationalmirrowonline.net/new/nigeria-health).

Moreover external medical referrals which are mostly done for the highly placed in society cannot be done without the recommendation of Nigerian doctors who are also involved in the decision-making.

In the developed countries, such as the United Kingdom and the United States of America, non medical doctors are the drivers of decisionmaking in the health sector. In other parts of Africa too non medical doctors are also visible drivers of health decision-making. In Ghana, for example, Ms Hanny-Sherry Ayittey, a Minister of Health (February 2013-June 2014), is a non doctor. In South Africa, although former Health Ministers, Nkosazana Dlamini Zuma (1994-1999) and Mantombazana (Manto) Shabalala Msimang (1999-2008) were doctors by training, they were also active politicians but with stints of higher training in public health. Yet in these countries medical tourism has not assumed the level it is in Nigeria and this can be attributed to the leadership abilities and knowledge of the appropriate officers which may be lacking in a medical doctor Minister.

To recall, in ancient times it was philosophers like Hippocrates and Plato who played key role in their societies that led to the development of both medicine and politics. For instance, Hippocrates developed the Hippocratic Oath that medical graduates swear to before they begin the journey of medical practice. Political development can also be traced to philosophers like Socrates and Moses in the Holy Bible. In fact, politics as the science of governance has remained the basis of decision-making for allocation of resources in the management of human affairs. This means that both disciplines have a common characteristic in the art of decision-making. Thus, when left in the hand of a doctor-politician, a human being becomes the object of decisions to restore or maintain normalcy in health.

\section{Common denominator for medicine and politics}

Using the instrument of decision-making for resource allocation it can be seen that medicine manages the body of a patient (an individual) while politics manages the body politics of a people (a nation). Both therefore have their common denominator in body management. These bodies are organic in the sense that they are those of living persons and being that they belong to the members of the public their management must also be of public interest. Even so, whereas in politics the organic body of the nation is the collective of the individual members of the public, in medicine the organic body is that of the individual members of the public.

Plato in The Republic, (cited in Varma, 2004:21 and Krakeur, 1992) described the true State as being a healthy State. What that suggests is that 
a true nation is a living nation, and comprises of a healthy body or a healthy group of bodies. In fact, Krakeuer suggests that there is a relationship between health (medicine) and politics. This is demonstrated when the German State carried out a cleansing exercise from the German nation of Jews. In that exercise, the author indicated that it was the physicians and health workers, who were used by the politicians. It therefore indicates that the physicians, as state health care agents, collaborated with politicians in the cleansing exercise. Similarly in 1927 the eugenic case of Carrie Buck and the United States Supreme Court ruling that she be sterilised (http://en.wikipedia.org/wiki/Carrie_Buck) demonstrated the State or politicians (the Supreme court as its agent) acting in collaboration with sterilizing agents, medical profession. Thus, whether it is at the level of the group of individuals or just the individual, medicine and politics act or take decisions on a common denominator, the organic body of human beings.

\section{A common call to service}

Krakeur (1992, cited in Mamora, 2005) suggested that Rudolf Virchow was more specific in describing the relationship between medicine and politics when he referred to medicine as Social Sciences and politics as medicine on a grand scale. In other words, whereas politics is Social Sciences on a grand (large) scale, medicine is Social Sciences on a petit (small) scale. Therefore if both professions are related in the Social Sciences, and the concept of Social Sciences refers to a science of the human society, it follows that whether one is involved in politics or in medicine there is an implication of a similar call to serve the organic body within human society. This is either in the art of governing the body of people or in the art of curing the body of people. Thus, when Mamora says that medical doctors often keep away from active politics, what he was suggesting is that doctors are not serving in the large scale Social Science. That is correct but it hides the truth that, as in politics, doctors are also serving the body even though on a small scale. In fact, there is nothing like active politics to suggest that there is passive politics. Rather, some are called to large scale service while others to small scale service. This is clearly illustrated in the gospel parable of Jesus whereby different persons were called and given different talents, depending on their ability
(The Holy Bible St. Matthew Chapter 25 and verse 15).

\section{Active or passive service}

In an editorial in the Canadian Medical Association Journal (CMAJ, 1933), Dr. Ross Mitchell said that when medical doctors go into politics, they remain as devoted as to their primary job. According to Mitchell, this is because the doctor-politicians "bring the sootiness of their bedside manner to compose the ruled nerves of parliamentary assemblage." The author believes that having been in intimacy with the people, doctors are "more likely to be called than to call" into politics. Can it then be said that those who are called into small scale Social Science should abandon their primary calling into a large scale Social Science which may be their secondary calling? A calling into a primary service certainly also suggests a calling into active service. To think otherwise would be a diminution of professional calling.

In Nigeria, even though politics has had brilliant medical people like Mamora and Okediran, $\mathrm{Dr}$ Dalhatu Tafilda, Dr. Jubril Aminu and Dr Martins Yellowe, (the man who first introduced the National Health Bill in the Senate), some medical politicians have left bitter pills in their calling to service. For instance, the first Executive Governor of Rivers State (1999-2007) left the health system not as exciting as would be expected of a state governed by a medical doctor. In that case one cannot say that the governor served the state in an active capacity especially in his primary calling. Dr. Olusola Saraki (May 1933 - Nov 2012) was popularly known to be the 'godfather' of Kwara State politics. This was because of the degree to which he managed the body politics of Kwara State. Having discovered politics as his primary calling Olusola Saraki became so active that from among his children, he produced two in active politics, one a Senator and the other Governor in Kwara State (currently the President of the Senate of Nigeria). Before leaving office as Governor in 2011 the latter laid the foundation that led to the FT/IFC Transformational Business Award won in 2016 by the Kwara State Health Insurance Programme as agent for Sustainable Development (www.thisdaylive.com/index.php/2016/..). 
On the $15^{\text {th }}$ of January 2014 NTA reported the successful operation of a kidney transplant in Delta State. The fact that Dr. Emmanuel Uduaghan, a medical politician was the Governor then, who necessitated that achievement, by actual involvement in the decision for resource allocation that led to the feat, it does not necessarily mean that he was an active member of the surgical team. Yet he played his active part in the health politics as others of his colleagues played their active part in the health care of the people, with both still fulfilling their calling in the service to humanity through effective body management.

\section{A call to self or public interest}

In the said lecture by Okediran, he suggested that medical doctors should go into politics for the sake of the public interest. Does this suggest that in their chosen profession doctors are not serving the public interest? But Glaser (1960) observed that members of the American Medical Association (AMA) rarely abandon medicine for lay career in governmental jobs. This, according to the author, is because the participation of AMA members in partisan politics is limited. In other words the rarity of AMA members getting involved in politics does not suggest a lack for the public interest. Rather, it is because their "distinctive orientation towards politics follows from the characteristic typical of a very successful social elite, .... whose ... work routine is very different from the ordinary work of government" (Glaser, 1960:66). This is not so for a Nigerian doctor who without recourse to his primary calling or any limitations can switch between politics and medicine any time. The problem in this limitless orientation to politics is that quality may be compromised in health care. For instance, it is certain that a PhD holder in medical laboratory science with specialization in Haematology, one who started the journey from Haematology as major at the first degree level, cannot be compared with a consultant doctor Haematologist who only ventured into Haematology with minor knowledge of medical microbiology from the MBBS programme. Nevertheless the doctor would still want to be the Head of that Department.

Any tendency which shows superiority of professions indicates a deficiency that is self interest-oriented and has largely accounted for the failing health system in Nigeria. In 2008, when Rotimi Amaechi was inaugurated as Governor of Rivers State, he inherited a 'failed' health system left behind by a medical doctor politician. Although Amaechi is not a doctor, but as a politician he improved the health system by establishing an enduring primary health care infrastructure for the people.

Thus even among the medical doctors in politics we can distinguish between core politicians from peripheral politicians. The former are those who provide high quality service by the health politics they practised. The opposite is the case for the peripheral politicians. When the core medical politicians are in office they advance the cause of the public interest in health, but the peripheral medical doctor politicians fail to achieve. Paul writing to the Galatians (Gal. 6:10) admonished them to do good to all but more especially to those of the same constituency. The same should apply to doctors whether in medical practice or health politics. In 2013 Adams Oshiomhole, former Governor of Edo State, speaking at the first National Health Summit organized by the Nigerian Medical Association (NMA) described the attitude of medical doctors towards their patient as "careless" (www.deltaoshobe.wordpress.com).

In that summit Comrade Oshiomhole complained about how a medical doctor who was absent from receiving a patient at a public health facility, was rather found in a private health facility receiving the same patient. It is such doctors who would be looking for opportunity as proposed by Okediran, to go into politics and when they do it is to satisfy their self interest. Therefore, it would be wrong to say that medical doctors are keeping away from active politics. It would also be wrong to put them in a situation whereby they begin to involve themselves in politics by abandoning their primary calling. Whether they are in politics or in medicine, medical doctors should be seen to be practising one form of Social Science or the other and should be encouraged or allowed to serve the public interest so (Bennett and Brown, 1993: 695-699).

\section{A duty in the call to serve}

From all indications there is a duty in the call to serve and this duty is found in both medicine and politics. That duty is an active one that must be demonstrated. It is a duty of care, established between persons by oaths, statutes and even 
contracts. This duty is defined as a legal obligation to act towards others and the public with cautious watchfulness and prudence in such a manner that a reasonable person in the same circumstances would (www.legal-dictionary.the freedictionary.com). In this duty whereas the politician is called to provide cure to societal (public) ills, the medical doctor is called to provide cure to an individual's ills.

But Jean Watson (in Leninger and Vanice, 2003) observed that "curing cannot occur without caring." This emphasises an earlier analysis of the concept of care by Henry (1991). Henry stated that "the moral/value features of care link with respect for the persons". In other words, in the process of a professional curing an individual or a society's ills, and so long as a duty of care is established over the professional's constituents, it demands also for respect to be shown towards those individuals or group of persons in that constituency. By this the legal and moral implications of the duty of care should make it difficult for the health workers to abandon their duty posts or go to do any other job for which they are not appropriately or properly trained to do. In similar circumstances politicians are not expected to abandon their duty posts simply because the people have failed to cooperate, as in keeping to rules governing human conduct in society.

Thus, for both professions to be involved in undue conducts while on duty suggests a lack of care and disrespect to the personhood of the human being. Such conduct would demonstrate a self-serving value system apparent in the general body politics of a country. It undermines the body management system, thereby making it obvious that not much attention is being given to the concept of duty of care. Dwight (1908) described the situation better when he observed that for both medicine and politics, the legal duty of care imposes an obligation to serve. This is more so when the politicians or medical doctors swear to an oath or sign a social contract for the functions they undertake to perform. By this even if duty can be synonymous with obligation, a duty of care becomes a legal indebtedness owed when that duty has been attached to something that is agreed but is not performed.
Leninger and Vanice (2003) observed that although the concept of care is important in medicine, it is not as central as it is in the nursing profession, Etekpe and Okolo (2011) have also shown that the interconnection of care is so important that where a politician ignores it, he/she may not elicit the confidence of the electorate to be re-elected. The same is applicable in medicine. Where a doctor is inefficient and loses patients he may face the disciplinary panel of their regulatory body for malpractice or misconduct. Thus since medical doctors work very closely with nurses, it is obvious that curing cannot occur without caring. The two concepts of cure and care must therefore impose upon medicine and politics the duty to ensure that the public interest is protected at all times. Between both professions where this is not happening, politicians have described medical doctors as careless towards their patients and medical doctors have described politicians as "illiterates who do not know what it takes to become a doctor" (Daily Sketch, 1981). Such tendency to accusations and counter accusations among members of related professions is bound to erode respect for each other and a loss of prestige for the professions.

\section{Why do doctors want more of their members to involve in politics?}

For doctors calling on themselves to go into politics there may be an attempt by them to regain a waning prestige and influence. The efforts of the two medical parliamentarians cited in this paper suggest this move. This is however, occurring in a disrespectful manner to the point of a conscious abandonment of the duty of care to the patient. The disrespect is seen in the accusations and counter accusations between medical practitioners and politicians, the latter among whom are also doctors. In both of 2013 and 2014, the medical profession embarked on two major strike actions that soured the relationship between medicine and politics. In 2014, this was evident when the Minister of Health (doctor in politics) challenged the NMA (doctors in medicine) to a debate over the protection of public interest. In fact, in the same period the NMA refused to suspend a strike despite a national emergency declared in the health sector when Ebola Virus Disease hit Nigeria. 
The point of convergence between medicine and politics

There is no doubt that medicine and politics are related. In the analyses above it is shown that to be involved in politics is a calling into leadership. But the behavioural theory of leadership suggests that leadership can be learned (https://iedunote.com/ohio-state-leadership studies..). Education is one means of making leaders, and from examining the medical education curriculum, it is clear that what Dr.
Virchow called medicine on a grand scale, is actually the politics of health (public health). In other words, whereas both professions of medicine and politics are related in the social sciences, they converge with each other in the arena of public health. The Table below shows areas of relationship between medicine and politics. This knowledge should eliminate the apparent disrespect often exercised by these professions towards the public and towards their related professional groups.

Table 1: Related characteristics in the calling between medicine and politics

\begin{tabular}{|lll|}
\hline Characteristic features & Medicine & Politics \\
Area of calling & Body of patients & Body of people \\
Specificity in calling & Cure of individual ills & Cure of public ills \\
Scale of calling & Small & Large \\
Level of operation & Individual & Public \\
\hline
\end{tabular}

Wilmslow, (1920) defined public health as;

"the art and science of preventing disease, prolonging life and promoting physical health and efficiency through organised community efforts for the sanitation of the environment, the control of community infections, the education of the individual in the principles of personal hygiene, the organization of medical and nursing services for the early detection and preventive treatment of disease, and the development of the social machinery which will ensure to every individual in the community a standard of living adequate for the maintenance of health."

Whereas this definition of public health is allembracing the key element is that of 'the organised efforts of community.' Public health is learned and the skills are taught. Thus, for the public health specialist or the medical doctor in politics what he needs to be effective is organizational skills (in resource allocation) and communication skills (in community mobilization). That being the case and as far as medicine and politics are concerned, medicine in politics should be left for those who have trained or are called to serve in that special field of medicine. Although in medical education the acquisition of skills in public health is introduced at the undergraduate level, full scale public health training (at a school or by experience) is a programme of its own running up to a doctorate level.
Furthermore, the main objective of public health in medical education is to ensure that medical doctors have the skills to enable the health facilities get fixed and functioning, as well as ensure that all that is related to health are made available and accessible. Moreover since in medicine there is a specialty called public health, it is in that specialty that one can ensure the leadership effectiveness of doctors who go into politics. It is also medical doctors and others who train to specialize in public health that can be in the best position to practice politics or large scale social science. This is because, since politics is about leadership, it would be required that those who aspire to practice it should possess the learnable behavioural attributes of leadership. Failure to possess these attributes manifests in a leadership or status gap (Paul, 1963). Hence Sagay (2013), advocates for good leadership as the only way to save Nigeria.

Looking at all these suggests that when Mamora said that medical doctors keep away from active politics he meant that they are not well equipped with the behavioural attributes of leadership even in health politics. Or it suggests a deficiency in medical doctors to apply organizational and community mobilization skills acquired or learned from public health training for the body management of society. This is one area where some emphasis should be placed in the effort at making a medical doctor in anticipation for his/her involvement in the politics of health. 
A public health example of the convergence between medicine and politics

Having identified public health as the point of convergence between medicine and politics, one health problem that clearly demonstrates this is HIVIAIDS. Writing on the politics of this disease Daini (2002) observed "nearly a decade ago, a few bricks were chipped out of the wall of silence erected by political leaders around the fearful subject of AIDs. In Africa this was when Ugandan President, Yoweri Museveni, faced with rising sickness and death in his country, reversed his long-standing opposition to the public prescription of condom and urged the medical and political disciplines to cooperate in addressing the scourge." Similarly in Kenya former President, Daniel Arap Moi said this about the disease;

Anything that can be said or done to halt the progress of the disease must be said and done (Daini, 2002:123).

In Nigeria former President, Olusegun Obasanjo in 2000 pressed the United Nations Security Council to place HIVIAIDS in Africa at the centre of world political agenda. Etekpe (2009) had also emphasised the socio-medical role of government by identifying ways in which this role can be carried out. In terms of training the behavioural theory leadership has opened the way and doctors are currently embracing it by enlisting in a new health management programme (a subset of public health) running in some universities. In a private discussion by one of the authors of this paper, lecturers at the University of Nigeria (Nsukka), indicated that more doctors are enrolling on the programme. This will give doctors more and a better leverage to acquiesce to politics.

\section{CONCLUSION}

This paper has shown that medicine and politics converge in the discipline of public health. Moreover because both professions are related in the Social Sciences if a medical doctor must be the Minister of Health, that is, to practice politics, especially in appointive position, it is from that field that such appointment can best be made. Thus for medical doctors to get involved in politics they would need to acquire leadership skills appropriate to the practice of politics. This they can get from the Social Sciences, management science and humanities courses like medical sociology, medical ethics, health management and psychology. Although these courses are already being introduced at the undergraduate level of medical education, they can be further developed at the postgraduate level.

But it is not automatic that all public health specialists will become good politicians or that the medical (doctor) politicians are good public health practitioners. Nevertheless, for the public health practitioner, the politician and the medical politician in particular, any failure in professional responsibility is a legal and moral obligation owed the society in the duty of care. At the same time to move from medicine into politics is a leadership challenge that would require the possession of leadership attributes learnable from the disciplinary field of public health. This means that social scientists should also be acknowledged as important stakeholders in the making of the medical doctor. Absence of this acknowledgement may be contributing to the underdevelopment in the health sector in Nigeria.

\section{REFERENCES}

Bennett, R. V. and Brown, L. K., 1993. Myles Textbook for Midwives. London: ELBS.

CMAJ, 1933. Editorial: Doctors in Politics. Canadian Medical Association Journal, Nov, 1933:29(5), 557-558. Comment attributed to Dr. Ross Mitchell in a tribute to medical men in the Winnipeg Free Press of 28 August 1930. (www.ncbi.nlm.nih.gov/pmc/articles/pmc4 03111). Accessed 22 July 2015, 5.30 pm.

Daily Sketch, 1981. Statement is quoted in McFubara, KG. (1998). Health Policy in Nigeria, PhD thesis submitted to the University of Manchester 1998, p. 282, from Daily Sketch newspaper March 24, 1981 p.6.

Daini, W., 2002. HIV/AIDS: Restoring hope and life. Lagos: Frankad Publishers.

Etepke, A., 2009. African Political thought and its relevance in contemporary World Order. Port Harcourt: Harvey Publication Coy. 
Etepke, A and Okolo, P. P., 2011. Politics and Democracy in Contemporary Nigeria. International Journal of Social Sciences, vol. 3(2): 429-430.

Dwight, W., 1908. Political science: Tradition, Discipline, Progression science, Enterprise. In Handbook of Political Science, American Political Science Review, vol. 1: 1-130.

Glaser, W. A., 1960. Doctors and Politics. American Journal of Sociology, Vol. 66, no 3. 230-

Henry C., 1991. Reasonable Care: Approaches to health care research. Journal of Advances in Health and Nursing Care, Vol. 1:4; 79-89.

http://en.wikipedia.org/wiki/Carrie_Buck.accessed 11 March 2018.

Krakeuer E., 1992. Medicine and Politics. The Yale Journal of biology and medicine, 65 : 243-249.

Leininger, M. Madelene Leininger's culture care: diversity and universality theory, chapter 15

$$
p
$$

(http://nursing.jbpub.com/sitzmanch15pdf .pdf). Accessed 2/6/2014 11.30pm

Mamora O., 2005. Medicine and Politics: The meeting point. Lecture delivered at the first Professor TAl Grillo distinguished Alumni lecture series, February 10, at Obafemi Awolowo University, Ile-Ife, Nigeria.
Okediran, W., 2014. Serving three masters: the interplay between medicine, literature and politics. A lecture delivered at the 30th induction ceremony for the University of llorin medical graduands. (http//dailyindependentnig/2014/06/medic al-doctors-advised-get-involved) accessed 31August 2014.

Paul, B. D., 1963. Anthropological perspectives on medicine and public health. The Annals of the American Academy of Political and Social Science, 346:34-43.

Plato, The Republic. In Verma, S. P. 2nd edition, 2004. Modern Political Theory, New Delhi: Vikas Publishing House, 4d, p.21.

Sagay, I., 2013. Good Governance and Enforcement of Law and Order. Management in Nigeria Journal. p. 6-15.

The Holy Bible. Matthew 25: 15 and Galatians 6:10. (The King James Version).

Vanice, T. Caring and the professional practice of nursing. (http://rnjournal.com/journal-ofnursing/caring-and-the-professionalpractice-of). Accessed 2/06/2014, 11 pm.

Wilmslow, C.E.A., 1920. Wilmslow's classic definition of public health, 1920. (www.maine,gov/dhhs/mecdc/localpublic-health/phddistrict1/document).

www.thisdaylive.com/index.php/2016/. 